\title{
Assesment of Human Mammaglobin (hMAG) as a New Marker for Early Diagnosis of Breast Cancer
}

\author{
ZEINAB A. ABD EL-HAFEZ, M.D.*; MOHAMMED I. SEDDIK, M.D.*; KHALED M. RIZK, M.D.** and \\ YASMIN T. EL-GAMMAL, M.Sc.* \\ The Departments of Clinical Pathology, Faculty of Medicine* and Clinical Oncology, South Egypt Cancer Institute**, \\ Assiut University, Assiut, Egypt
}

\begin{abstract}
Background: Breast cancer may originate either from the ducts, known as ductal carcinomas or from the lobules, known as lobular carcinomas. There are many different types of breast cancer, with different stages (spread), aggressiveness, and genetic makeup. Breast cancer is the most frequent cancer in women affecting approximately $6 \%$ of the females. It constitutes almost $20 \%$ of all malignancies in women. In Egypt, breast cancer affects $37.7 \%$ of all women and accounts for $29.1 \%$ of their cancer-related mortality with a total of 6546 deaths.

Aim: The aim of this study is to study correlations between hMAG level and different stages of breast cancer (TNM staging) and to study correlations between hMAG as a new marker and routine markers used in breast cancer (CA 15-3 \& CEA).

Patients and Methods: This study was carried out on 80 Breast Cancer female patients their age ranged aged 25 to 65 years. Ten age matched healthy females served as controls. Patients were referred from Assiut University Hospital, General Surgery Department, and South Egypt Cancer Institute. Formal consent was obtained from patients and controls. The study was approved by Ethical Committee of Faculty of Medicine Assiut University.
\end{abstract}

Results: None of the healthy females in control group (group1) had elevated mammaglobin level above the cut-off value which was $41.49 \mathrm{ng} / \mathrm{ml}$. Elevated levels of mammaglobin was detected in $65 \%, 75 \%, 90 \%$ and $100 \%$ of patients in groups II, III, IV, and V respectively. There was a significant positive correlation between Mammaglobin positivity with CEA and CA 15-3 concentrations. The combination CA153 , CEA and mammaglobin resulted in the highest sensitivity $(97 \%)$, highest specificity (95\%) and highest diagnostic accuracy $(96 \%)$.

Conclusion: Mammaglobin levels in peripheral blood samples obtained from Egyptian female individuals with breast cancer, are good markers for detection of breast cancer. This marker can be used to aid in detection of metastasis as

Correspondence to: Dr. Yasmin T. El-Gammal, E-mail: Yasminelgamal@hotmail.com it is correlated with the clinical staging of the disease. A combination of CA15-3, CEA and mammaglobin may be used as a panel for diagnosis of metastasis among breast cancer patients.

Key Words: Breast Cancer - Human Mammaglobin - Cancer antigen 15-3 (CA 15-3) - Carcinoemberyonic antigen (CEA).

\section{Introduction}

BREAST cancer is the most frequent cancer in women affecting approximately $6 \%$ of all females. It constitutes almost $20 \%$ of all malignancies in women. Despite recent advances in early diagnostic and treatment strategies, breast cancer is still a leading cause of cancer-related deaths among women, with as many as $40 \%$ relapsing with metastatic disease [1]. In Egypt, breast cancer affects 37.7\% of all women and accounts for $29.1 \%$ of their cancer-related mortality with a total of 6546 deaths [2]. Breast cancer may originate either from the ducts, known as ductal carcinomas, or from the lobules, known as lobular carcinomas. There are many different types of breast cancer, with different stages (spread), aggressiveness, and genetic makeup

Carcinoembryonic antigen (CEA) and Cancer antigen 15-3 (CA 15-3) are commonly used markers for breast cancer. However, they lack sensitivity and specificity, are rarely elevated prior to gross disease, and are not seen in many patients with metastases. Many other biomarkers have been suggested for detecting breast cancer in tissues, peripheral blood and/or bone marrow including human mammaglobin [4]. Cancer cells produce CEA in large amounts, but it can also be found in the blood of healthy people. It showed less sensitivity than CA 15-3 in both early and advanced breast cancer [5]. CA 15-3 Lacks sensitivity for 
early-stage disease combined with a lack of specificity for the early diagnosis of breast cancer. CA 15-3 concentrations are increased in $10 \%$ of patients with stage I disease, $20 \%$ with stage II disease, $40 \%$ with stage III disease, and $75 \%$ with stage IV disease [6].

Human mammaglobin (hMAG) is a member of the uteroglobin proteins family that has recently been tested as a specific marker for breast cancer. While low levels may be seen in normal breast tissue, expression is increased dramatically in breast cancer. This promises to be a useful screen for early detection of breast cancer, especially in high risk individuals [7].

The aim of this study is to study correlations between hMAG level and different stages of breast cancer (TNM staging) and to study correlations between hMAG as a new marker and routine markers used in breast cancer (CA 15-3 \& CEA).

\section{Patients and Methods}

This study included eighty breast cancer female patients aged 25 to 65 years. Ten age-matched females served as controls. Patients were referred from Assiut University Hospital, General Surgery Department, and South Egypt Cancer Institute over a period of 1 year duration from January 2016 to January 2017. Formal consent was obtained from both patients and controls. The study was approved by Ethical Committee of Faculty of Medicine, Assiut University. Female patients with any other type of malignant or benign tumors and those with past history of chemotherapy or surgical treatment of cancer, were excluded from the study.

Staging of Breast cancer patients was done according to the American Joint Committee of Cancer (AJCC) staging system and the TNM staging system [8].

Patients and controls were grouped as follows:

Group 1: Included 10 controls.

Group 2: Included 20 patients with stage I breast cancer.

Group 3: Included 20 patients with stage II breast cancer.

Group 4: Included 20 patients with Stage III breast cancer.

Group 5: Included 20 patients with stage IV breast cancer.

Sample collection, storage, and handling:

A total of eight ml of venous blood were collected; two ml into EDTA containing tube for complete blood count, two $\mathrm{ml}$ into sodium citrate containing tube for prothrombin time and concentration, and Four ml into plain tube without anticoagulant.

Blood was allowed to clot for 15 minutes at $37^{\circ} \mathrm{C}$ and serum was separated by centrifugation at 3000 rpm for 10 minutes. Collected serum was inspected to ensure it was clear and non-hemolyzed or lipaemic and then divided into three aliquots; one for kidney functions, random blood sugar, and liver functions, another for CEA and CA-15-3, and the third was stored at $-20^{\circ} \mathrm{C}$ until assay of Human Mammaglobin level was performed.

\section{Routine investigations:}

Random blood sugar, serum urea, serum creatinine, liver functions were done on Dimension ${ }^{\circledR}$ RxL Max ${ }^{\circledR}$ Integrated Chemistry System-Siemens. Prothrombin time and concentration were done on Sysmex CA-1500 System-Siemens [9]. Complete blood count was done on CELL-DYN 3700-Abbott.

\section{Special investigations:}

Quantitative measurement of Carcinoembryonic Antigen and the cancer antigen 15-3 levels in serum was done using solid-phase, chemiluminescent immunometric assay on IMMULITE 1000 analyzer (Siemens Medical Solutions Diagnostic Limited, UK). Normal range for the CEA is $0.11-5.09 \mathrm{ng} / \mathrm{ml}$ (Cat. no. 363238) and for the CA $15-3$ is $6.4-58$ IU/ml (Cat. no. 249755).

\section{Measurement of human mammaglobin level:}

This was done by ELISA technique and read on Stat-Fax 303 plus. (Cat. no.: A0220).

\section{I- Test principle:}

Purified human mammaglobin is allowed to coat microtiter plate and make solid phase antibody. Samples or standards are added to wells with a labeled antibody specific to mammaglobin, then labeled HRP is added to the wells. After washing completely, TMB substrate solution is added. TMB substrate becomes blue color in wells that contain antibody-antigen-enzyme-antibody complex. Reaction is terminated by the addition of a solution and the color change measured at a wavelength of $450 \mathrm{~nm}$. The concentration of mammaglobin in the samples is then determined by comparing the optic density of the samples to the standard curve.

\section{II- Preparation of samples:}

Samples were diluted 1:5 in sample dilution buffer before use (40 Ssample dilution +10 testing sample). 


\section{III- Test procedure:}

All reagent and samples were stored at room temperature $\left(15-30^{\circ} \mathrm{C}\right)$ and mixed well.

1- Standard was diluted to make serial dilutions.

\begin{tabular}{lcccccc}
\hline Tube & 0 & 1 & 2 & 3 & 4 & 5 \\
ug/l & 320 & 160 & 80 & 40 & 20 & 10 \\
\hline
\end{tabular}

2- Fifty awe added to wells from both standard and testing samples.

3- The plate was covered by adhesive strip and incubated at $37^{\circ} \mathrm{C}$ for $30 \mathrm{mins}$.

4- Wash solution was diluted 20 folds with distilled water.

5- Washing: the adhesive strip was removed, fluid discarded and washing buffer was added to each well for 30 seconds and repeated 5 times.

6- Fifty Lon to each well except the blank well.

7- The plate was covered by adhesive strip and incubated at $37^{\circ} \mathrm{C}$ for 30 mins.

8- The adhesive strip was removed, fluid discarded and washing buffer was added to each well for 30 seconds and repeated 5 times.

9- Fifty Lofechromogen solution A and B was added to each well for $15 \mathrm{mins}$ at $37^{\circ} \mathrm{C}$ and light was avoided.

10- Fifty stop solution was added to each well to stop the reaction (the blue color was changed to yellow color).

\section{Statistical analysis:}

The data were tested for normality using the Anderson-Darling test and for homogeneity variances prior to further statistical analysis. Categorical variables were described by number and percent $(\mathrm{N}, \%)$, where continuous variables described by mean and standard deviation (Mean, SD). Chisquare and fisher exact tests used to compare between categorical variables where compare between continuous variables by unpaired $t$-test. Pearson correlation coefficient used to assess the association between continuous variables. A twotailed $p<0.05$ was considered statistically significant. All analyses were performed with the IBM SPSS 20.0 software.

\section{Results}

\section{1- Carcinoembryonic Antigen (CEA) levels:}

In group1, CEA level ranged from 1.60-4.50 $\mathrm{ng} / \mathrm{ml}$ (mean $\pm \mathrm{SE}=3.18 \pm 0.29 \mathrm{ng} / \mathrm{ml}$ ) with cut-off $5.07 \mathrm{ng} / \mathrm{ml}$. In group 2, CEA level ranged from
$1.50-15.50 \mathrm{ng} / \mathrm{ml}$ (mean $\pm \mathrm{SE}=4.46 \pm 0.86 \mathrm{ng} / \mathrm{ml}$ ). Sensitivity was $25 \%$ and specificity was $100 \%$ with cut-off at $5.07 \mathrm{ng} / \mathrm{ml}$. In group 3 , CEA level ranged from $1.20-14.40 \mathrm{ng} / \mathrm{ml}$ (mean $\pm \mathrm{SE}=4.52$ $\pm 0.67 \mathrm{ng} / \mathrm{ml}$ ). Sensitivity was $30 \%$ and specificity was $100 \%$ with cut-off at $5.07 \mathrm{ng} / \mathrm{ml}$. In group 4 , CEA level ranged from $2.60-55.30 \mathrm{ng} / \mathrm{ml}$ (mean \pm $\mathrm{SE}=10.66 \pm 2.56 \mathrm{ng} / \mathrm{ml}$ ). Sensitivity was $75 \%$ and specificity was $100 \%$ with cut-off at $5.07 \mathrm{ng} / \mathrm{ml}$. In group 5, CEA level ranged from 2.30-22.40ng $/ \mathrm{ml}$ (mean $\pm \mathrm{SE}=11.48 \pm 5.49 \mathrm{ng} / \mathrm{ml})$. Sensitivity was $100 \%$ and specificity was $75 \%$ with cut-off at $5.07 \mathrm{ng} / \mathrm{ml}$. The number and percentage of cases with normal ( $\leq$ cut off) and high (>cut off) level of CEA in different studied groups are shown in Table (1).

Table (1): The number and percentage of cases with normal ( $\leq$ cut off) and high (>cut off) level of CEA in different studied groups.

\begin{tabular}{lcccc}
\hline \multirow{2}{*}{ Groups } & \multicolumn{2}{c}{ Normal } & \multicolumn{2}{c}{ High } \\
\cline { 2 - 5 } & No. & $\%$ & No. & $\%$ \\
\hline Group 1 $(\mathrm{N}=10)$ & 10 & 100 & 0 & 0 \\
Group 2 $(\mathrm{N}=20)$ & 15 & 75.0 & 5 & 25.0 \\
Group 3 $(\mathrm{N}=20)$ & 16 & 80.0 & 4 & 20.0 \\
Group 4 $(\mathrm{N}=20)$ & 5 & 25.0 & 15 & 75.0 \\
Group 5 $(\mathrm{N}=20)$ & 5 & 25.0 & 15 & 75.0 \\
\hline
\end{tabular}

No.: Number.

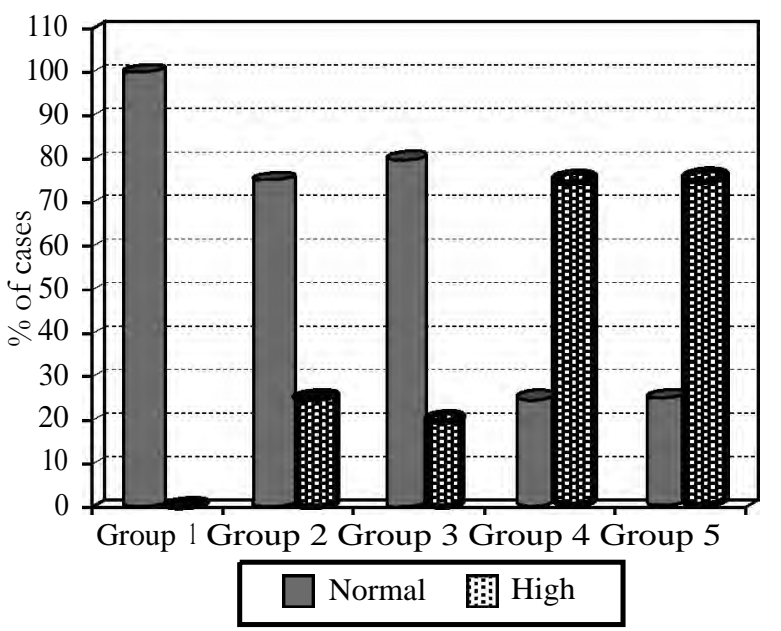

Fig. (1): The percentage of cases with normal ( $\leq$ cut off) and high ( $>$ cut off) values of CEA in different studied groups.

\section{2- Carcinoma Antigen 1 5-3 (CA 1 5-3) levels:}

In group 1, CA15-3 level ranged from 7.90$30.0 \mathrm{IU} / \mathrm{ml}$ (mean $\pm \mathrm{SE}(15.33 \pm 2.33 \mathrm{IU} / \mathrm{ml})$ with cut-off at $30.09 \mathrm{IU} / \mathrm{ml}$. In group 2, CA15-3 level ranged from 17.3-66.0IU $/ \mathrm{ml}$ (mean $\pm \mathrm{SE}=43.63 \pm$ $3.14 \mathrm{IU} / \mathrm{ml}$ ). Sensitivity was $50.0 \%$ and specificity was $95 \%$ with cut-off at $30.09 \mathrm{IU} / \mathrm{ml}$. In group 3, CA15-3 level ranged from 33.8-84.2IU/ml (mean 
$\pm \mathrm{SE}=54.58 \pm 3.33 \mathrm{IU} / \mathrm{ml})$. Sensitivity was $65 \%$ and specificity was $95 \%$ with cut-off at $30.09 \mathrm{IU} / \mathrm{ml}$. In group 4, CA15-3 level ranged from 33.0-182.0 $\mathrm{IU} / \mathrm{ml}$ (mean $\pm \mathrm{SE}=86.35 \pm 11.66 \mathrm{IU} / \mathrm{ml}$. Sensitivity was $85 \%$ and specificity was $95 \%$ with cut-off at $30.09 \mathrm{IU} / \mathrm{ml}$. In group 5, CA15-3 level ranged from $30.0-166.0 \mathrm{IU} / \mathrm{ml}$ (mean $\pm \mathrm{SE}=74.83 \pm 10.46 \mathrm{IU} / \mathrm{ml}$. Sensitivity was $95 \%$ and specificity was $98 \%$ with cut-off at $30.09 \mathrm{IU} / \mathrm{ml}$. The number and percentage of cases with normal ( $\leq$ cut off) and high (>cut off) values of CA15-3 in different studied groups are shown in Table (2).

Table (2): Number and percentage of cases with normal ( $\leq$ cut off) and high (> cut off) levels of CA15-3 in different studied groups.

\begin{tabular}{lcccl}
\hline \multirow{2}{*}{ Groups } & \multicolumn{2}{c}{ Normal } & \multicolumn{2}{c}{ High } \\
\cline { 2 - 5 } & No. & $\%$ & No. & $\%$ \\
\hline Group 1 $(\mathrm{N}=10)$ & 10 & 100.00 & 0 & 0.0 \\
Group 2 $(\mathrm{N}=20)$ & 10 & 50.0 & 10 & 50.0 \\
Group 3 $(\mathrm{N}=20)$ & 7 & 35.0 & 13 & 65.0 \\
Group 4 $(\mathrm{N}=20)$ & 3 & 15.0 & 17 & 85.0 \\
Group 5 $(\mathrm{N}=20)$ & 1 & 5.0 & 19 & 95.0 \\
\hline
\end{tabular}

No.: Number.

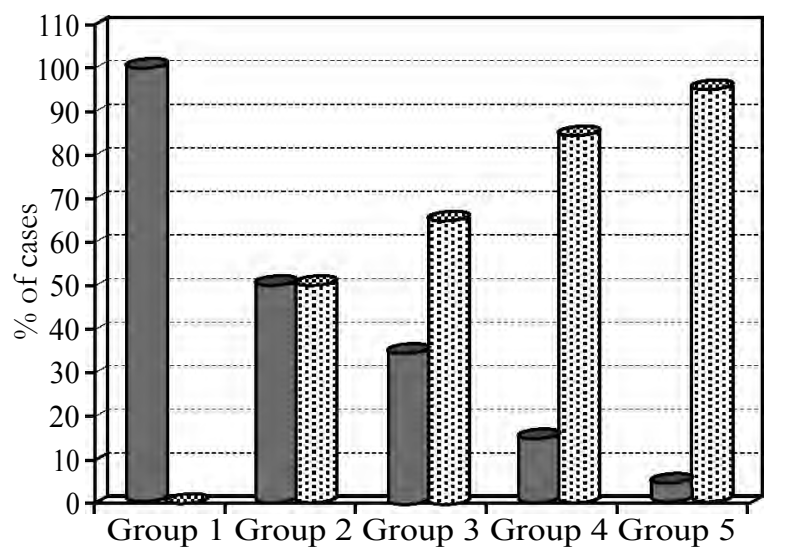

$$
\square \text { Normal 国 High }
$$

Fig. (2): Percentage of cases with normal ( $\leq$ cut off) and high ( $>$ cut off) values of CA 15-3 in different studied groups.

\section{3- Human Mammaglobin ( $M M A G$ ) levels:}

In group 1, hMAG level ranged from 25.3-38.4 $\mathrm{ng} / \mathrm{ml}$ (mean $\pm \mathrm{SE}=31.57 \pm 1.56 \mathrm{ng} / \mathrm{ml}$ with cut-off at $41.49 \mathrm{ng} / \mathrm{ml}$. In group 2, hMAG level ranged from $25.0-47.8 \mathrm{ng} / \mathrm{ml}$ with mean $\pm \mathrm{SE}=33.07 \pm$ $1.30 \mathrm{ng} / \mathrm{ml}$. Sensitivity was $65.0 \%$ and specificity was $90.0 \%$ with cut-off at $41.49 \mathrm{ng} / \mathrm{ml}$. In group 3 , hMAG level ranged from 27.3-58.4 ng/ml (mean \pm $\mathrm{SE}=42.73 \pm 10.39 \mathrm{ng} / \mathrm{ml}$. Sensitivity was $75.0 \%$ and specificity was $95.0 \%$ with cut-off at $41.49 \mathrm{ng} / \mathrm{ml}$. In group 4, hMAG level ranged from 34.7-
$88.4 \mathrm{ng} / \mathrm{ml}$ (mean $\pm \mathrm{SE}=65.15 \pm 15.24 \mathrm{ng} / \mathrm{ml}$. Sensitivity was $90 \%$ and specificity was $98 \%$ with cutoff at $41.49 \mathrm{ng} / \mathrm{ml}$. In group $5, \mathrm{hMAG}$ level ranged from $54.8-110.3 \mathrm{ng} / \mathrm{ml}$ (mean $\pm \mathrm{SE}=87.01 \pm 16.44 \mathrm{ng}$ $/ \mathrm{ml}$. Sensitivity was $100 \%$ and specificity was $100.0 \%$ with cut-off at $41.49 \mathrm{ng} / \mathrm{ml}$. The number and percentage of cases with normal ( $\leq$ cut off) and high ( $>$ cut off) values of hMAG in different studied groups are shown in Table (3).

Table (3): Number and percentage of cases with normal ( $\leq$ cut off) and high ( $>$ cut off) values of hMAG in different studied groups.

\begin{tabular}{lcccl}
\hline \multirow{2}{*}{ Groups } & \multicolumn{2}{c}{ Normal } & \multicolumn{2}{c}{ High } \\
\cline { 2 - 5 } & No. & $\%$ & No. & $\%$ \\
\hline Group 1 $(\mathrm{N}=10)$ & 10 & 100.0 & 0 & 0.0 \\
Group 2 $(\mathrm{N}=20)$ & 7 & 35.0 & 13 & 65.0 \\
Group 3 $(\mathrm{N}=20)$ & 5 & 25.0 & 15 & 75.0 \\
Group 4 $(\mathrm{N}=20)$ & 2 & 10.0 & 18 & 90.0 \\
Group 5 $(\mathrm{N}=20)$ & 0 & 0 & 20 & 100.0 \\
\hline
\end{tabular}

Chi square test. No.: Number.

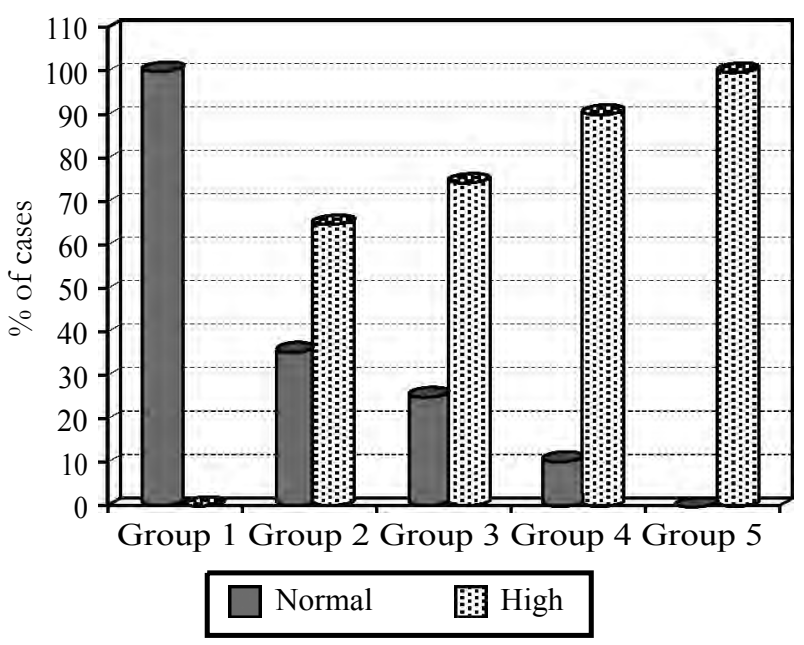

Fig. (3): Percentage of cases with normal ( $\leq$ cut off) and high ( $>$ cut off) values of hMAG in different studied groups.

Correlation between CEA and Mammaglobin levels:

There is a significant positive correlation between CEA and Mammaglobin ( $r=0.301$ and $p<0.05)$.

Table (4): Correlation between CEA and Mammaglobin.

\begin{tabular}{lcc}
\hline Test & $r$-value & $p$-value \\
\hline CEA \& Mammaglobin & 0.301 & $0.007^{* *}$ \\
\hline
\end{tabular}

Pearson correlation.

** Moderate statistical significant difference $(p=0.001)$. 


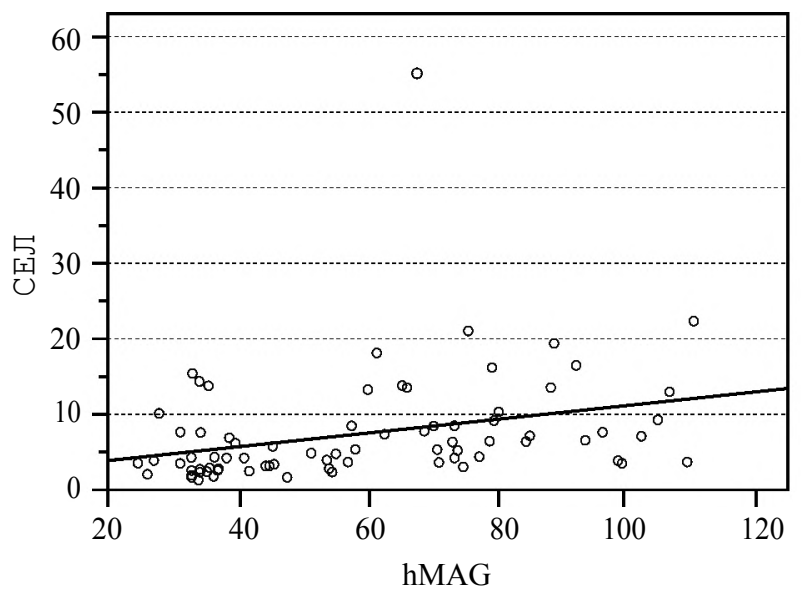

Fig. (4): Correlation coefficients between CEA and Mammaglobin levels.

Correlation coefficients between CA15-3 and Mammaglobin levels:

There is a significant positive correlation between CA15-3 and Mammaglobin ( $r=0.313$ and $p<0.05)$.

Table (5): Correlation between CA 15-3 and Mammaglobin.

\begin{tabular}{lcc}
\hline Test & $r$-value & $p$-value \\
\hline CA 15-3 \& Mammaglobin & 0.313 & $0.003^{* *}$ \\
\hline $\begin{array}{l}\text { Pearson correlation. } \\
* * \text { Moderate statistical significant difference }(p=0.001) .\end{array}$
\end{tabular}

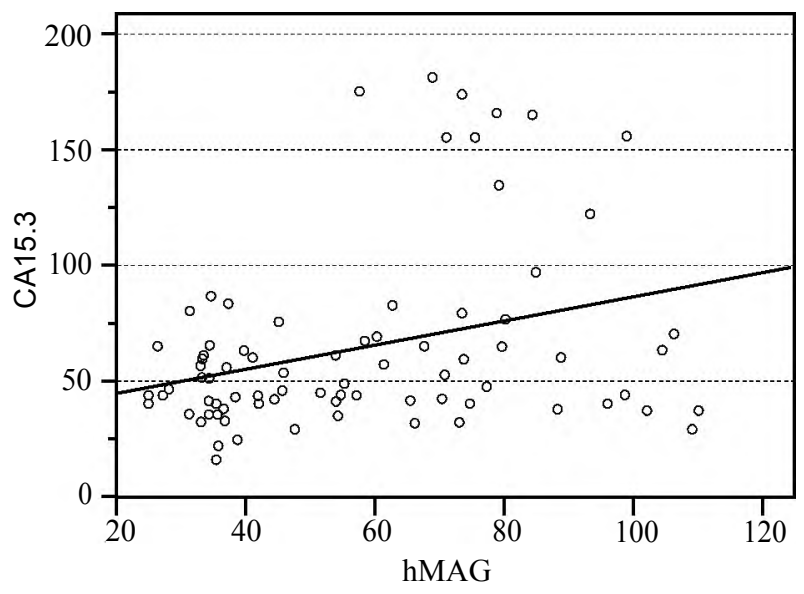

Fig. (5): Correlation coefficients between CA15-3 and Mammaglobin levels.

Sensiti vity and specificity of CA15-3, CEA and Mammaglobin in all patients groups: Table (6)

The combination of tumor markers is considered positive if any one of the markers level is above the cut off value. On the other hand, the combination of tumor markers is considered negative only if all the markers were below or equal the cut off value.
Table (6): Sensitivity, specificity and diagnostic accuracy of the markers in all patients groups.

\begin{tabular}{llcc}
\hline Items & Sens. & Spec. & DA \\
\hline CA 15-3+CEA & 94 & 95 & 94 \\
CA 15-3+Mammaglobin & 95 & 95 & 95 \\
CEA+Mammaglobin & 72.1 & 100 & 74 \\
CA 15-3+CEA+Mammaglobin & 97.0 & 95 & 96 \\
\hline
\end{tabular}

Sens: Sensitivity. Spec: Specificity. DA: Diagnostic accuracy.

\section{Discussion}

Breast cancer is the most frequent cancer in women. Its incidence is high and constantly increasing. It constitutes almost $20 \%$ of all malignancies in women. Despite recent advances in early diagnostics and treatment strategies, breast cancer is still a leading cause of cancer-related death among women, with as many as $40 \%$ relapsing with metastatic disease [1]

Mammaglobin, known as a specific marker for mammary tissue, has been considered a promising diagnostic marker in breast cancer for almost 10 years. In particular, the application of mammaglobin techniques to detect disseminated breast cancer cells has been reported. Much work has evaluated the detection of mammaglobin in lymph nodes, blood, and bone marrow aspirate of breast cancer patients. Structural details about the mammaglobin complex have also been discovered, and these findings can be used to optimize detection of the secreted protein. The peculiarity of hMAG lies in its almost sole existence in mammary tissue and mammary carcinoma. In addition, its high expression in carcinomas and its association with tumor grades renders it an excellent marker for diagnosis and prognosis [7].

This study was performed on ninty females divided into 5 groups: 10 healthy females as a control group (group 1), 20 patients with stage I cancer (group 2), 20 patients with stage II cancer (group 3), 20 patients with stage III cancer (group 4) and 20 patients with stage IV cancer (group 5).

In the current study, none of the healthy females in the control group (group 1) had elevated CEA above the cut-off value which was $5.07 \mathrm{ng} / \mathrm{ml}$, while elevated levels of CEA were detected in $25 \%, 20 \%$, $75 \%$, and $75 \%$ of patients in groups $2,3,4$, and 5 respectively. These results are consistent with those reported by Fiorella et al., [10] and Amr et al., [11], who found elevated CEA levels $16,22 \%$ and $67.5 \%$ of patients with stage I, II and IVcancer respectively. However, in patients with stage III cancer, elevated CEA levels were found in $37.3 \%$ patients 
only (cut-off value was $5 \mathrm{ng} / \mathrm{ml}$ ). On the other hand, our results are inconsistent with those reported Gao et al., [12], who found that CEA was elevated in $4.7 \%, 3.5 \%, 2 \%$, and $38 \%$ of patients with stage I, II, III, and IV cancer respectively. This can be explained by the fact that CEA can also be elevated in some non-cancerous diseases, like cirrhosis, chronic kidney disease, chronic obstructive pulmonary disease (COPD), rheumatoid arthritis, and in otherwise healthy smokers [13].

Similarly, none of the healthy females in the control group (group 1) (0.0\%) had elevated CA 153 level above the cut-off value which was 30.09IU/ $\mathrm{ml}$, while elevated levels of CA 15-3 were detected in $50,65 \%, 85 \%$, and $95 \%$ of patients in groups $2,3,4$, and 5 respectively. This is consistent with the findings of Park et al., [14] and Nasizadeh [15] who carried out a research on serum CA15-3 in different stages of breast cancer. On the contrary, Dai et al., [16] found that CA15-3 was elevated in $7.7 \%, 20.6 \%, 35.7 \%$ and $63.5 \%$ of patients with stage I, II, III, IV breast cancer respectively, (Cut off: $21.8 \mathrm{U} / \mathrm{ml}$ ). This can be explained by the fact that increased concentrations of CA 15-3 may be elevated in patients with benign ovarian cysts, benign breast disease, and benign liver disease. Elevations may also be seen in cirrhosis, sarcoidosis and lupus [17].

Elevated mammaglobin level above the cut-off value $41.49 \mathrm{ng} / \mathrm{ml}$, were not detected in the patients of the control group, while it was found in $65 \%$, $75 \%, 90$, and $100 \%$ of patients with stage I, II, III, and IV breast cancer respectively. These results are consistent with those reported by Lee et al., [18], who detected evaluated mammaglobin mRNA in $23.4 \%, 35.8 \%, 65 \%$, and $82.5 \%$ of patients with stage I, II, III, and IV cancer respectively. Contrary to these findings, Galvis-Jiménez [19] reported no correlation between levels of mammaglobin and clinical stage of the disease. This may be due to that the study was conducted on patients in early stages only and on small number of patients.

Results showed that there was a significant positive correlation between mammaglobin positivity and CEA and CA 15-3 concentrations. Dalia et al., [20], compared mammaglobin positivity with CEA and CA 15-3 concentrations, and found statistically significant correlation with CEA, and not with CA15-3 levels. Contrary to these results, El Attar et al., [21], studied 40 Egyptian females with primary breast cancer., and found no correlation between mammaglobin levels and both CEA and CA15-3. This was explained by Antonella et al., [22], who reported that higher levels of CA 15-3 and CEA are correlated with a larger tumor burden and a more advanced disease. The serum levels of CA 15-3 and CEA increase as cancer develops. In metastatic breast cancer, the highest levels of CA 15-3 and CEA are often seen when the cancer has spread to the bones and/or to the liver. Also, mammaglobin is limited to the mammary gland. A correlation between increased expression of mammaglobin and breast cancer was reported. Mammaglobin is present in high levels in metastatic breast cancer and primary breast cancers as compared to non-malignant breast tissue [23] .

Our results showed that the combination CA153 , CEA and mammaglobin resulted in the highest sensitivity (97\%), the highest specificity $(95 \%)$ and the highest diagnostic accuracy (96\%).

It can be concluded that mammaglobin levels in peripheral blood samples obtained from Egyptian female individuals with breast cancer, are good markers for detection of breast cancer. This marker can be used to aid in detection of metastasis as it is correlated with the clinical staging of the disease. A combination of CA15-3, CEA and mammaglobin may be used as a panel for diagnosis of metastasis among breast cancer patients.

\section{References}

1- PARKIN M., BOYD L., and WALKER C.: The fraction of cancer attributable to lifestyle and environmental factors in the UK in 2010. Summary and conclusions', British Journal of Cancer, 105 (S2): S77-S81, 2011.

2- ELKHODARY T., EBRAHIM M., HATATA E. and NIAZY N.: Prognostic value of lymph node ratio in nodepositive breast cancer in Egyptian Patients, 1397-1401, 2013.

3- CHATTERJEE S., MUKHERJEE M.M., NATH N.H., SAMANTA M. and SAHA K.A.: An observational study on the incidence of HER-2/neu receptor over- expression and comparison of clinical presentation between HER2/neu positive and HER-2/neu negative breast cancer "Int. Surg. J., 4 (2): 506-513, 2017.

4- MARIC ' P., OZRETIC' P., LEVANAT S., ORESKOVIC' S., ANTUNAC K. and BEKETIC-ORESKOVIC' L.: Tumor markers in breast cancer- evaluation of their clinical usefulness. Coll. Antropol., 35: 241-7, 2011.

5- GRANATO A., FRASSINETI G., GIOVANNINI N. and BALLARDINI M.: Do Serum Angiogenic Growth Factors Provide Additional Information to That of Conventional Markers in Monitoring the Course of Metastatic Breast Cancer?, 2006.

6- DUFFY M.J.: Serum Tumor Markers in Breast Cancer: Are They of Clinical Value? Clinical. Chemistry, p. 52: 3 345-351, 2006.

7- AL-JOUDI F.S.: Human mammaglobin in breast cancer: A brief review of its clinical utility. Indian. J. Med. Res., 139: 675-85, 2014. 
8- American Joint Committee on Cancer (AJCC): Breast. In: Edge SB, Byrd DR. and Compton CC.: AJCC Cancer Staging Manual. 7th ed. New York, NY: Springer, pp. 347-76, 2010.

9- TOBU M., IQBAL O. and HOPPENSTEADT D.: Anti$\mathrm{Xa}$ and anti-IIa drugs alter International Normalized Ratio measurements: Potential problems in the monitoring of oral anticoagulants. Clin. Appl. Thromb. Hemost. 10: 301-9. Toward Precision Medicine of Breast Cancer, 2004.

10- FIORELLA G., PATRIZIA F. and SANDRO C.: A ReEvaluation of Carcinoembryonic Antigen (CEA) as a Study Serum Marker for Breast Cancer: A Prospective. Clin. Cancer. Res., 7: 2357-2362, 2001.

11- AMR SAAD MOHAMMED, AZZA ABD-ALLA MOHAMMED, AMAL MOHAMMED NOUR-ELDIN, AHMED MOSTAFA AHMED and MOSTAFA SAIFELNASR: Evaluation of Activated Leukocyte Cell Adhesion Molecule as a Biomarker for Breast Cancer in Egyptian Patients. Academic Journal of Cancer. Research, 6 (1): 29-37, 2013.

12- GAO J., ZHANG Q., XU J., GUO L. and LI X.: Clinical significance of serum miR-21 in breast cancer compared with CA153 and CEA. Chinese Journal of Cancer. Research, 25 (6): pp.743-748, 2013.

13- NAGPAL M., SINGH S., SINGH P., CHAUHAN P. and ZAIDI M.A.: Tumor markers: A diagnostic tool. National Journal of Maxillofacial Surgery, 7 (1): p. 17, 2016.

14- PARK B.J., CHA M.K. and KIM I.H.: Thioredoxin 1 as a serum marker for breast cancer and its use in combination with CEA or CA15-3 for improving the sensitivity of breast cancer diagnoses. BMC Research Notes, 7 (1): p. 7, 2014.

15- NASIZADEH S.: Serum CA15-3 measurment in Breast Cancer patients before and after mastectomy. Archives of Iranian Medicine, Volume 8, Number 4: 263-266, 2005.

16- DAI D., CHEN B., TANG H., WANG B., ZHAO Z., XIE $X$. and WEI W.: Nomograms for Predicting the Prognostic
Value of Pre-Therapeutic CA15-3 and CEA Serum Levels in TNBC Patients. PloS one, 11 (8): p. e0161902, 2016.

17- YOTSUKURA S. and MAMITSUKA H.: Evaluation of serum-based cancer biomarkers: A brief review from a clinical and computational viewpoint. Critical reviews in oncology/hematology, 93 (2): pp.103-115, 2015.

18- LEE GW., KIM JY., KOH EH., KANG D., CHOI DS., MAENG KY. and LEE JS.: Plasma human mammaglobin mRNA associated with poor outcome in patients with breast cancer. Genetics and Molecular Research, 11 (4): 4034-4042, 2012.

19- GALVIS-JIMÉNEZ J.M., CURTIDOR H., PATARROYO M.A., MONTERREY P. and RAMÍREZ-CLAVIJO S.R.: Mammaglobin peptide as a novel biomarker for breast cancer detection. Cancer Biology \& Therapy, 14 (4): pp. 327-332, 2013.

20- DALIA KADRY, AMAL FAWZY, IMAN A. ABDELGAWAD, IMAN LOAY H. ABULKHEIR and FATMA M.A. ABOU EL KASEM: Detection of Mammaglobin mRNA in the Blood of Breast Cancer Egyptian Female Patients and Its Relation to Established Prognostic $\mathrm{Pa}-$ rameters. Life Science Journal, 10 (2), 2013.

21- EL-ATTAR N.I. and GAEFAR H.A.: Plasma mammaglobin messenger RNA in breast cancer patients as an addition to serum tumor. Egypt. J. Immunol., 14: 111-21, 2007.

22- ANTONELLA D., ROSA D., PAOLO T., MARIA E., ANGELO P., PORZIA C., INES A., MICHELE Q. and ANTONIO M.: Clinical Usefulness of Cancer Antigen 15-3 in Breast Cancer Patients Before and After Surgery. The Open Breast Cancer Journal, 5: 1-6, 2013.

23- Span P.N., Waanders E., Manders P., Heuvel J.J., Watson M.A., Beex L.A., Sweep F.C.: Mammaglobin Is Associated With Low-Grade, Steroid Receptor-Positive Breast Tumors From Postmenopausal Patients, and Has Independent Prognostic Value for Relapse-Free Survival Time Journal of Clinical Oncology, 22 (4): 691-698, 2004. 


\section{تقيييم الماماجلوبين البشرى كدلالة جلديلة

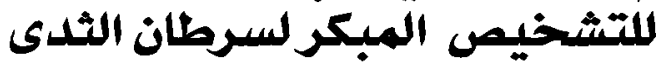

$$
\text { اجريت هذه الدراسة على ثمانين إمرأة مصابة بسرطان الثدى وقد اجريت لهم التحاليل الآتية: }
$$

نسبة السكر، وظائف الكلى وظائف الكبد، وصورة دم كاملة وزمن وتركيز برثيروبين، الأضافة الى عشرين امرأة من الأصحاء ظاهرياً كمجموعة ضابطة وكانت النتائج كالآتى:

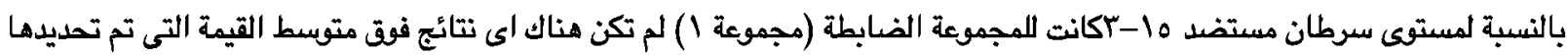

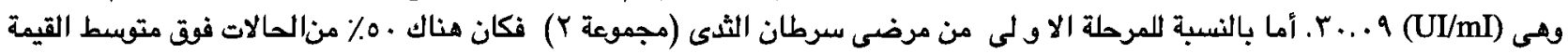

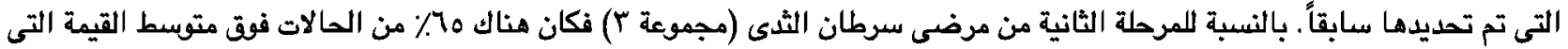

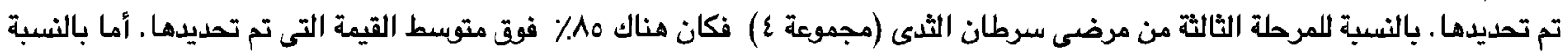

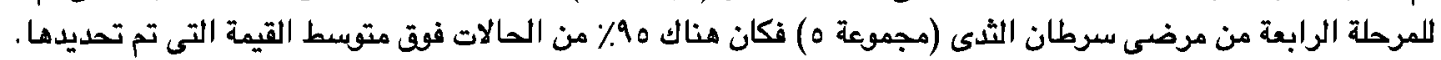

بالنسبة لمستوى الكا رسينو امريونك انتيجين للمجموعة الضابطة (مجموعة () لم تكن هناك ایى نتائج فوق متوسط القيمة التى تم تصديدها

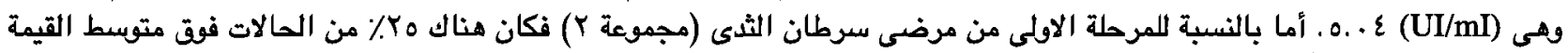

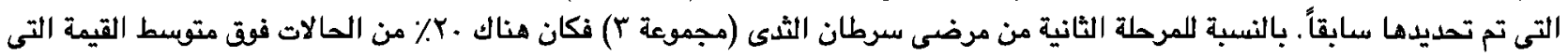

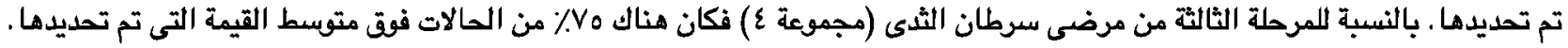

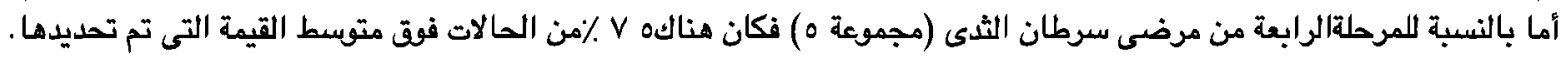

بالنسبة لمستوى الما ماجلوبين البشرى المجموعة الضابطة (مجموعة () لم تكن هناك اى نتائج فوق متوسط القيمة التى تم تصديدها

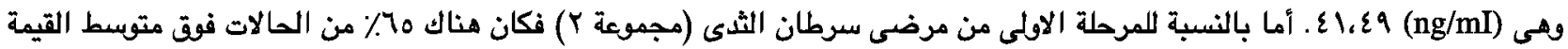

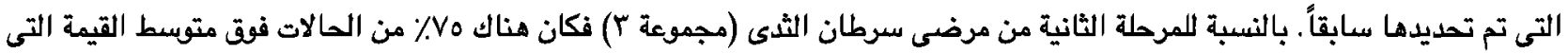

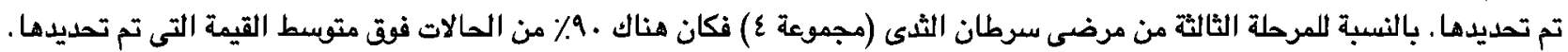
أما بالنسبة للمرحلةالرابعة من مرضى سرطان الثدى (مجموعة م) فكان هناك ـ. ـ1\% من الحالات فوق متوسط القيمة التى تم تحديدها. معامل الارتباط بين دلال الأورام سرطان مستضد 15-3 والكارسينو امبريونك انتجين والماماجلوبين:

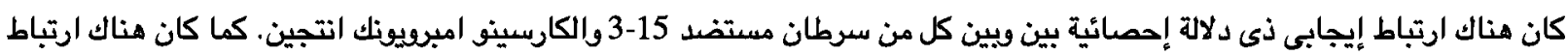
إيجابى ذى دلالة إحصائية بين الماماجلوبين وبين كل من سرطان مستضين إنس وبن 15-3 والكارسينو امبرويونك انتجين. 